\title{
A note on the effect of feeding calves on fish-protein-based milk replacers
}

\author{
Lj. Sretenovic \\ Institute for Animal Husbandry \\ Autoput 16. 11080 Zemun -Beograd. Yigoslavia \\ (Received 3 April 2000; accepted 4 October 2000)
}

\section{ABSTRACT}

The effect of feeding calves of the Black-and-White East Friesian breed on milk replacers based on proteins of animal origin were investigated. Skim milk powder was substituted at the levels of 0 , 25,50 and $75 \%$ by protein from fish protein concentrates produced using enzymatic hydrolysis. The performance of calves, i.e. body weight and daily gain. was assessed and nutrient digestibility and nitrogen balance were estimated.

There were no differences in daily liveweight gain during the whole period of the study (about $790-830 \mathrm{~g}$ ) and in the liveweight of calves at the end of experiment (about 127-132 kg). Up to 60 days of age the daily gains of calves from control group (without fish protein) were higher $(\mathrm{P}<0.01)$, $709 \mathrm{~g}$, than in remaining groups $(689-621 \mathrm{~g})$.

The results show that up to $75 \%$ of milk protein in milk replacers may be successfully substituted by fish protein concentrate protein without adversely affecting calf performance.

KEY WORDS: calves, milk repłacers, animal protein, digestibility, nitrogen balance, body weight, daily gain

\section{INTRODUCTION}

Skim-milk-powder-based milk replacers are very expensive and continuous intensification of milk and meat production has made it necessary to find more modern and economical solutions in the nutrition of calves by introducing alternative protein sources. Efforts went in the direction of including higher quality and cheaper protein sources in milk replacers. The most important among animal proteins are fish-based products. Despite the amino acid composition of fish proteins being very similar to that of milk, meat, and eggs, the use of conventional fish meal in milk replacers is very limited because of serious health problems that can 
arise due to imperfect technologies for producing fish meal for these purposes. By enzymatic hydrolysis it is, however, possible to obtain high quality fish protein (a common name for fish meal with a high protein content (over $80 \%$ ) is fish protein concentrate) characterized by high digestibility and biological value that guarantees the high quality of the final product. The success of hydrolysis depends on the properly chosen enzyme that is able to "dissolve" fish in only several hours. One of the reasons why fish protein concentrate was not used more widely is that it was not possible to produce it in sufficient quantity on an industrial scale. Nowadays, as the technology of enzyme production is developed, this problem has been solved.

Proteins originated from fish, provided in higher proportions (above $50 \%$ of protein value) were the subject of investigation of many researchers, i.e. Norman (1971), Opstvedt et al. (1978), Sretenovic et al. (1987), and Adamovic et al. (1995), but the results were unsatisfactory because of the poor quality of the protein substitutes.

The aim of this work was to investigate the maximum range of substitution of milk proteins in milk replacers with protein from fish protein concentrate in order to obtain optimal rationalizations in calf breeding.

\section{MATERIAL AND METHODS}

The experiment included 96 calves divided into 4 groups (A,B,C, D) of 24 heads each, uniform in liveweight, origin and sex ratio (1:1). Body weight was measured on day 10 after birth, which is considered the beginning of the trial, and then on days $30,60,90$, and 120 of life. The investigations were carricd out through feeding and balance trials. The feeding trial lasted from day 10 to 120 of life.

During the first 10 days of life, the calves were fed on colostrum and whole milk and then between days 10 and 20 of age they were gradually accustomed to the studied milk replacers. The effect of feeding calves on milk replacers with the substitution of $0,25,50$, and $75 \%(\mathrm{~A}, \mathrm{~B}, \mathrm{C}$ and $\mathrm{D})$ protein by fish protein concentrates was investigated.

Fish protein concentrate under the commcrcial name CPSP 90 used as a protein source in calf milk replacers was obtained by enzymatic hydrolysis of fish by the French firm, Sapropeche. The milk replacers were composed of skimmed milk powder, fish protein concentrate, whey powder, lard, maize starch, soya lccithin, emulgator, dicalcium phosphate, calcium carbonate, and a vitamin-mineral mixture. They contained: DM (\%) 96.9, 96.9, 97.1, and 97.4; protein (\%) 25.5, 25.5, 25.5, and 25.7; energy (MJ/kg) 9.2, 9.0, 8.9, and 8.7 in groups A, B, $\mathrm{C}$ and $\mathrm{D}$, respectively. The calves were given colostrum and milk replacers from buckets. The liquid food was fed until 60 days of age when the calves passed to 
the solid food, i.e. they were fed only a concentrate mixture. The concentrate mixture was pelleted and contained: DM, $89.3 \%$; crude protein, $17.7 \%$, and gross energy, $6.7 \mathrm{MJ} / \mathrm{kg}$.

Determination of nutrient digestibility in the diet and nitrogen balance were carried out during the liquid diet feeding period, i.e. in the 8th weck of life.

These determinations werc carried out by direct methods, collecting total faeces and urine in metabolism cages. Additional animals were used for this purpose. The preparatory period lasted 14 days and collection period, 5 days.

Chemical composition of feeds, facces and urine of were estimated according to AOAC (1990).

\section{RESULTS AND DISCUSSION}

The chemical composition of feeds is given in Table 1. The apparent digestibility of nutrients in the diet in the 8th week of life is shown in Table 2.

The results show that higher inclusion rates of protcin from fish protein concentrates $(0,25,50,75 \%)$ tended to lincarly reduce apparent digestibility of dry matter, which ranged between 87.5 and $85.3 \%$. Differences between the treatments were not statistically significant. Similarly, organic matter digestibility tended to decrease with the increase of the non-milk protein level, and in treatments A,B,C and $\mathrm{D}$ it accounted for $88.5,87.4,87.1$, and $86.3 \%$, respectively.

Crude protein digestibility tended to decrease linearly with the increase of the fish protein level in milk replacers, which was confirmed in practice by body weight changes, i.e. average daily gains. From the physiological point of view, the decrease of digestibility with the increase of non-milk protein level is logical and

TABLE I

Chemical composition of feeds, $\%$

\begin{tabular}{lcccccc}
\hline \multicolumn{1}{c}{ Feed } & $\begin{array}{c}\text { Dry } \\
\text { matter }\end{array}$ & $\begin{array}{c}\text { Crude } \\
\text { protein }\end{array}$ & $\begin{array}{c}\text { Crude } \\
\text { fat }\end{array}$ & $\begin{array}{c}\text { Crude } \\
\text { fibre }\end{array}$ & NFE & Ash \\
\hline Colostrum, day 0 & 20.65 & 13.80 & 2.83 & - & 3.02 & 1.00 \\
Whole milk & 12.43 & 3.25 & 3.73 & - & 4.76 & 0.69 \\
Milk replacer A & 96.90 & 25.48 & 14.56 & 0.57 & 49.62 & 6.67 \\
Milk replacer B & 96.85 & 25.48 & 13.96 & 0.56 & 49.64 & 7.21 \\
Milk replacer C & 97.13 & 25.46 & 14.10 & 0.34 & 51.90 & 5.33 \\
Milk replacer D & 97.39 & 25.70 & 15.24 & 1.40 & 47.00 & 8.05 \\
Starter-concentrate & 89.26 & 17.70 & 2.84 & 7.60 & 58.89 & 2.23 \\
Grower-concentrate & 89.46 & 16.31 & 2.73 & 7.04 & 59.98 & 3.40 \\
Skim milk powder & 94.21 & 32.61 & 0.69 & - & 53.83 & 7.08 \\
Fish protein concentrate & 97.16 & 84.34 & 6.02 & - & - & 6.80 \\
\hline
\end{tabular}


TABLE 2

Apparent nutrient digestibility in calves at 8 week of life, $\%$

\begin{tabular}{ccccccc}
\hline Treatments & $\begin{array}{c}\text { Dry } \\
\text { matter }\end{array}$ & $\begin{array}{c}\text { Organic } \\
\text { matter }\end{array}$ & $\begin{array}{c}\text { Crude } \\
\text { protein }\end{array}$ & $\begin{array}{c}\text { Crude } \\
\text { fat }\end{array}$ & $\begin{array}{c}\text { Crude } \\
\text { fibre }\end{array}$ & NFE \\
\hline A & 87.5 & 88.5 & 87.2 & 96.5 & 69.8 & 90.0 \\
B & 86.2 & 87.4 & 86.4 & 96.9 & 58.5 & 89.1 \\
C & 86.0 & 87.1 & 86.1 & 96.1 & 52.9 & 88.9 \\
D & 85.3 & 86.3 & 84.1 & 94.6 & 48.4 & 89.4 \\
\hline
\end{tabular}

expected, as its resorption is lower due to somewhat impaired curd formation and shorter retention time in the abomasum, causing greater nitrogen retention in excrements, as confirmed by the nitrogen balance. The results of these investigations suggest that the differences in digestibility of crude protein between treatments A and $\mathrm{D}$ ( 0 and $75 \%$ of fish protein) of only 3.14 percentage points or $3.6 \%$, indicate the high quality of the used product, which was obtained by enzymatic hydrolysis.

Digestibility of crude fat, cellulose, and NFE were also not significantly different $(\mathrm{P}>0.05)$.

The results of nitrogen balance investigations at 8 weeks of life are shown in Table 3.

TABLE 3

Nitrogen balance in calves at 8 weeks of life

\begin{tabular}{|c|c|c|c|c|c|c|c|c|}
\hline \multirow{2}{*}{ Group } & \multirow{2}{*}{$\mathrm{N}$ intake } & \multicolumn{2}{|c|}{$\mathrm{N}$ in faeces } & \multicolumn{2}{|c|}{$\mathrm{N}$ in urine } & \multicolumn{3}{|c|}{$\mathrm{N}$ retention } \\
\hline & & g/day & $\%$ of intake & g/day & $\%$ of intake & $\mathrm{g} /$ day & $\%$ of intak & of digestede \\
\hline A & 54.1 & 6.9 & 12.8 & 11.9 & 22.1 & 35.2 & 65.1 & 74.7 \\
\hline B & 53.8 & 7.3 & 13.6 & 12.3 & 22.9 & 34.1 & 63.5 & 73.4 \\
\hline $\mathrm{C}$ & 53.3 & 7.4 & 13.9 & 11.9 & 22.4 & 34.0 & 63.7 & 74.0 \\
\hline D & 52.6 & 8.4 & 15.9 & 11.7 & 22.2 & 32.5 & 61.9 & 73.6 \\
\hline
\end{tabular}

Analysis of the obtained results suggests that nitrogen intake was somewhat lower at higher levels of fish protein and the difference between treatments $\mathrm{A}$ and $\mathrm{D}$ of $1.53 \mathrm{~g}$ or $2.8 \%$ was practically negligible. The differences observed were not statistically significant $(\mathrm{P}>0.05)$. On the other hand, faecal $\mathrm{N}$ excretion increased as the non-milk protein level increased, and the differences between treatments $\mathrm{A}$ and $\mathrm{D}$ of $1.44 \mathrm{~g}$ /day were statistically significant $(\mathrm{P}<0.05)$. Faecal $\mathrm{N}$ excretion tended to be higher compared to $\mathrm{N}$ intake, and the 3.12 percentage units points difference between treatments $\mathrm{A}$ and $\mathrm{D}$ was highly significant $(\mathrm{P}<0.01)$, while the difference between treatments $\mathrm{B}$ and $\mathrm{D}$ of 2.34 percentage units was significant at $\mathrm{P}<0.05$. The differences among treatments in urinary $\mathrm{N}$ losses were very small and 
practically negligible. The balance between the $\mathrm{N}$ intake and excrement $\mathrm{N}$ loss determined daily $\mathrm{N}$ retention. $\mathrm{N}$ retention decreased with higher levels of fish protein in the diet, probably as a result of poorer quality of fish protein and poorer amino-acid content in the trial diets compared with the milk-based ones. Despite the linearly decreasing tendency, the differences in $\mathrm{N}$ retention were not significant. The results of this investigation are similar to those reported by Huber and Slide (1967), Raven (1972) and Opstvedt et al. (1977). In all the investigated treatments, $\mathrm{N}$ balance was positive and $\mathrm{N}$ retention decreased with higher level of fish protein.

Tables 4 and 5 show the average body weight and daily gain in calves. The linear tendency of decreasing body weights with higher levels of non-milk protein was most marked at 60 days of age. It is assumed that at this age faster anabolic processes cause higher muscular mass synthesis so that proteins of lower biological value than those in milk result in poorer daily gain and lower body weight. Thus, the difference between groups $\mathrm{A}$ and $\mathrm{C}$ of $3.01 \mathrm{~kg}$ or $4.0 \%$ was significant $(\mathrm{P}<0.05)$ while the difference of $4.67 \mathrm{~kg}$ or $6.2 \%$ between groups $\mathrm{A}$ and $\mathrm{D}$ was highly significant $(\mathrm{P}<0.01)$. Due to the phenomenon of compensatory growth, the lower body weight gain during liquid diet feeding was successfully improved in the solid diet feeding period, and at age of 120 days the calves gained at a satisfac-

TABLE 4

Average body weight, $\mathrm{kg}$

\begin{tabular}{lccccc}
\hline \multirow{2}{*}{ Treatment } & \multicolumn{5}{c}{ Age, days } \\
\cline { 2 - 6 } & 10 & 30 & 60 & 90 & 120 \\
\hline A & 40.2 & 53.0 & $75.73^{\mathrm{a} . \wedge}$ & 102.6 & 131.6 \\
$\mathrm{~B}$ & 40.1 & 52.5 & 74.6 & 101.7 & 130.6 \\
$\mathrm{C}$ & 39.9 & 51.7 & $72.7^{\mathrm{b}}$ & 100.1 & 129.4 \\
D & 40.0 & 51.3 & $71.1^{\mathrm{B}}$ & 97.8 & 127.2 \\
\hline
\end{tabular}

a.b $\mathrm{P}<0.05 ;{ }^{\wedge . \mathrm{B}} \mathrm{P}<0.01$

TABLE 5

Average daily gain, $\mathrm{g}$

\begin{tabular}{lcllcccc}
\hline \multirow{2}{*}{ Treatment } & \multicolumn{7}{c}{ Feeding period, days } \\
\cline { 2 - 7 } & $10-30$ & $30-60$ & $60-90$ & $90-120$ & $10-60$ & $60-120$ & $10-120$ \\
\hline $\mathrm{A}$ & $637^{\mathrm{a}}$ & $757^{\wedge}$ & 895 & 967 & $709^{\mathrm{a}, \Lambda}$ & 931 & 830 \\
$\mathrm{~B}$ & $619^{\mathrm{a}}$ & $735^{\mathrm{C}}$ & 903 & 964 & $689^{\mathrm{C}}$ & 934 & 822 \\
$\mathrm{C}$ & $591^{\mathrm{b}}$ & $701^{\mathrm{C}}$ & 912 & 976 & $657^{\mathrm{b}}$ & 944 & 814 \\
$\mathrm{D}$ & $568^{\mathrm{b}}$ & $657^{\mathrm{B}, \mathrm{D}}$ & 891 & 979 & $621^{\mathrm{B}, \mathrm{D}}$ & 935 & 792 \\
\hline
\end{tabular}

${ }^{a, b} \mathrm{P}<0.05 ;{ }^{\wedge . \mathrm{B}} \mathrm{P}<0.01 ;{ }^{\mathrm{C}, \mathrm{D}} \mathrm{P}<0.01$ 
tory rate for this age. In other words, in the liquid diet feeding period (10-60 days), the higher inclusion rates of fish protein proportionally reduced weight gains. Statistically significant differences shown in this period were completely compensated in the solid diet feeding period.

The results obtained in this study are essentially in accordance with the reports of other researchers who investigated fish protein of similar quality even with high levels of this product in milk replacers (up to $80 \%$ ) with very satisfactory results (e.g. Norman, 1971; Opstvedt et al., 1978; Jenkins et al., 1982) in respect to body weight and average daily gains. All of the animals were in good health.

\section{REFERENCES}

Adamovic M., Sretenovic L., Milosevic M., Simic D., Pudja P., 1995. Quality of milk replacers for calf nutrition based on different protein sources. Congress on Quality of Animal Product According to New Regulations. Beograd (Yugoslavia), pp. 110-113

Gorril A.D.L., Nicholson J.W.G., Larmond E., Power H.E., 1975. Comparison of fish protein sources and milk byproducts in milk replacers for calves. Can. J. Anim. Sci. 55, 269-278

Guilloteau R.P.. Toullec P.R., Grongnet J.F., Patureau-Mirand A., Prugnaud J., Sauvant D., 1986. Digestion of milk, fish and soya-bean protein in the prerumunant calf: flow of digesta. apparent digestibility of the ileum and amino acid composition of ileal digesta. Brit. J. Nutr. 55, 571-592

Huber J., Slade L. M.. 1967. Fish protein as a protein source of calf milk replacers. J. Dairy Sci. 50. 1296-1300

Jenkins J.K., Emmons D.B., Larmond E., Saucr F.D., 1982. Soluble partially hydrolized fish protein concentrate in calf milk replacers. J. Dairy Sci. 65, 784-792

Norman E., 1971. Fish protein concentrate in milk replacers. Proceedings of International Milk Replacer Symposium. Zurich, pp. 26-27

Opstvedt J.. Sobstad G., Hansen P., 1978. Functional fish protein concentrate in milk replacers for calves. J. Dairy Sci. 61, 72-82

Raven A.W., 1972. Nutritional effects of including different levels and sources of protein in milk replacers for calves. J. Sci. Food $\mathrm{Agr}$. 23, 517-526

Roy J.H.B., Stobo I.J.R., Susan M., Shotton A., Garderton P.. Gillies M.C., 1977. The nutritive value of non-milk proteins for the preruminant calf. The effect of replacement of milk protein by soya-bean or fish-protein concentrate. Brit. J. Nutr. 38, 167-187

Sretenovic L., Adamovic M., Markovic D., 1992. Milk replacers as a factor for improving production and rational milk consumption. Congress on Improvement of Cattle, Sheep and Goat Breeding for Higher Milk Production. Niska Banja (Yugoslavia), pp. 106-111

Sretenovic L.. Milosevic M., Adamovic M., Cobic T., 1987. Comparative investigation of the fish meal with regard to some major quality features and to its impact on the digestibility of calf diets, nitrogen balance and retention. International $\wedge$ ssociation of Fish Meal Manufacturers, 27 th Annnual Conference, Dubrovnik, pp. 164-179 


\section{STRESZCZENIE}

Wpływ zastąpienia bialka mleka chudego bialkiem rybnym w preparacie mlekozastępczym na rozwój cieląt

W doświadczeniu przeprowadzonym na 96 cielętach wschodnio-fryzyjskich czarno-białych, od urodzenia do 120 dni życia, badano wpływ zastąpienia białka mleka chudego w proszku białkiem preparatu rybnego w starterze na ich rozwój. Mleko chude zastąpiono w ilości O (grupa kontrolna), 25, 50, i 75\% koncentratem rybnym, otrzymanym na drodze hydrolizy enzymatycznej. Oznaczano m.c. cieląt, dzienne przyrosty, strawność składników pokarmowych oraz bilans azotu.

Nie stwierdzono różnic w dziennych przyrostach cieląt w ciągu całego doświadczenia (około $790-830$ g) i m.c. przy końcu doświadczenia (około 127-132 kg). Do 60 dnia życia (okres „mleczny"), przyrosty cieląt $\mathrm{z}$ grupy kontrolnej były większe $(\mathrm{P}<0,01 ; 709 \mathrm{~g})$ niż z pozostałych grup (689-621 g).

Otrzymane wyniki wskazują, że białko mleka w preparacie mlekozastępczym może być zastąpione białkiem koncentratu rybnego, w ilości do $75 \%$, bez ujemnego wpływu na rozwój cieląt. 